RESEARCH ARTICLE

\title{
Healing Waters and Buffalo Bones: Using Women's Histories to Challenge the Patriarchal Narrative of Lac Ste. Anne, Alberta
}

\author{
William T.D. Wadsworth* \\ Department of Anthropology, Faculty of Arts, University of Alberta
}

\begin{abstract}
Most historical narratives have overlooked women's roles in and Indigenous peoples' relationships with the Roman Catholic church, such as that of Lac Ste. Anne, a 19th century Roman Catholic community in Alberta. Lac Ste. Anne was the first permanent Catholic mission west of the Red River settlement and frequently appears in historical documents and missionary histories. Women and Indigenous peoples, however, are scantily mentioned. In contrast to the dominant patriarchal narratives built from decades of male-based stories, I propose that women's accounts from the settlement illuminate life and relationships between its inhabitants. Drawing on historical sources left by three Sisters of Charity (Grey Nuns), who maintained the chapel and founded the school and hospital in 1859, and oral histories from Victoria Callihoo, a Métis woman who lived in the settlement as a young girl, I will argue that the Catholic Fathers conflated women's lives at Lac Ste. Anne into one over-simplistic patriarchal narrative. Additionally, when re-examined with a 21 st century lens, these stories can inform the anthropological study of women at Lac Ste. Anne including their roles and responsibilities, living conditions, physical and social mobility, and relationships with colonialism.
\end{abstract}

Keywords: history, women and gender, Alberta, religious, Indigenous, anthropology

Early colonization occurred in areas of significance to Native people, in places like Manito Sakahigan. The early missionaries realized that these places would be good bases to work from ... Manito Sakahigan was God's lake, a healing lake. (Simon 1995, 3)

\section{INTRODUCTION}

In the past, women's roles in and Indigenous peoples' relationships with the Roman Catholic church have only been superficially discussed. The contributions of women have been generally overlooked by early missionary histories from the Canadian Prairies and thus represent a significant paucity in research. Since the founding of its Roman Catholic mission in 1843, Lac Ste. Anne, or Manito Sakahigan, has been an important place of religious worship and evangelism for Indigenous communities in Alberta and, as such, brought (and continues to bring) diverse

\footnotetext{
* Corresponding author (wwadswor@ualberta.ca)
} 
groups of people to the area (Simon 1995). The site is about $100 \mathrm{~km}$ northeast of the modern city of Edmonton, Alberta (Figure 1) and played a prominent role in the early settlement of the province (Palmer and Palmer 1990, 2627). In 1889, Fr. Joseph Lestanc founded the annual pilgrimage at Lac Ste. Anne, which has grown into the largest Catholic gathering in Western Canada (Simon 1995). Although a great deal of attention has been paid to the religious history entangled with the site, little focus has been paid to the Lac Ste. Anne settlement, which was a nineteenth century Roman Catholic community founded around the mission that largely consisted of Métis and Stoney Nakota inhabitants. Stories from several women at the Lac Ste. Anne settlement help illuminate the patriarchal narratives that have shaped the history of the area and reveal aspects of life in the settlement.

This research began as part of a larger archaeology project investigating Métis places in Alberta and Saskatchewan; however, the illuminating stories found at Lac Ste. Anne warranted their own historical research paper. In regard to methods, I scoured the Provincial Archives of Alberta (Edmonton, AB), Musée Héritage Museum (St. Albert, AB), Sisters of Charity Archives (Montreal, QC), and the Library and Archives Canada (Ottawa, ON) for materials relating to the women of the Lac Ste. Anne settlement.

From this literature review, two distinct sources from different temporal periods of the Lac Ste. Anne settlement were examined for this essay. First, in 1859, three Sisters of Charity (Grey Nuns) were sent from Montreal

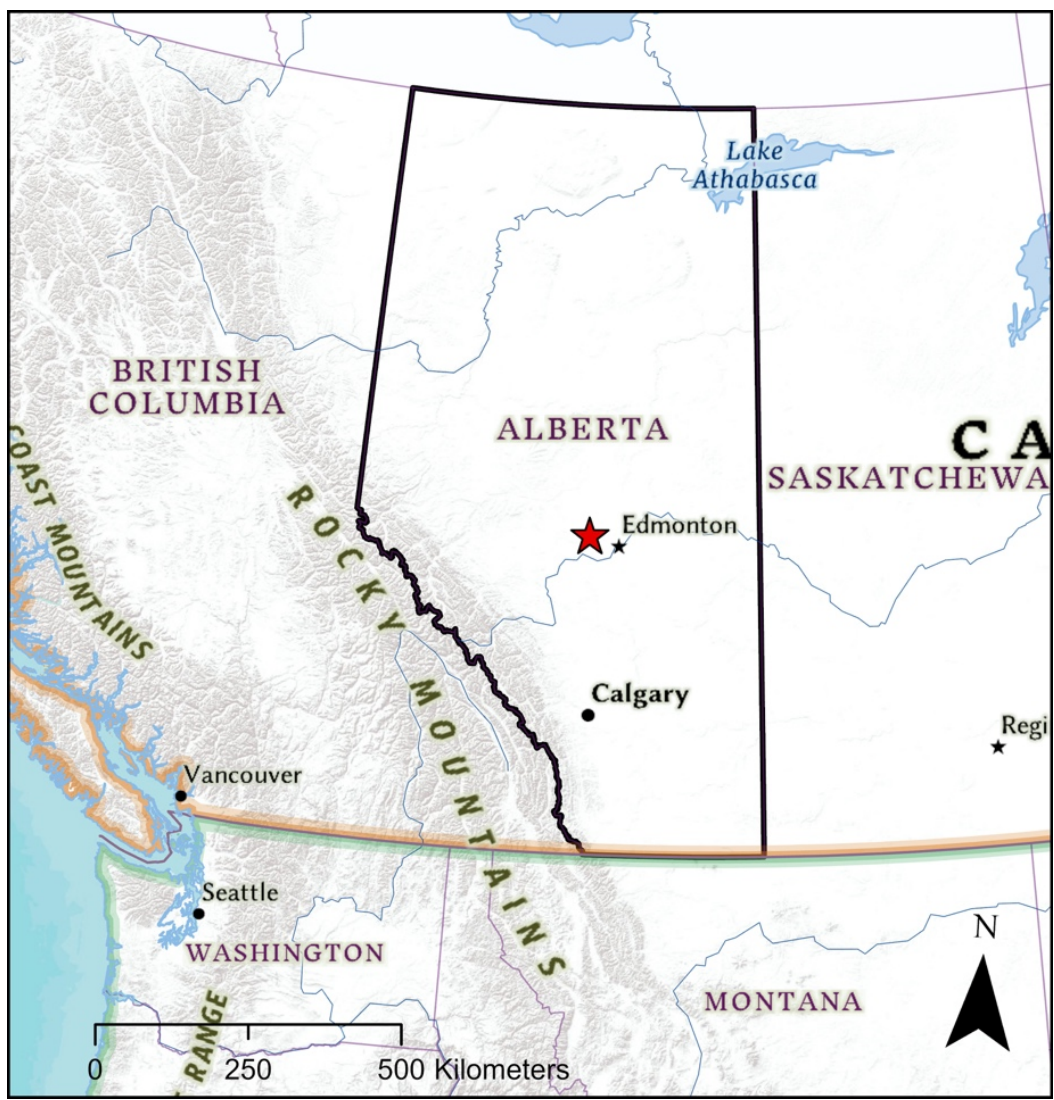

FIGURE 1-Map depicting the location of the Lac Ste. Anne settlement (indicated by a star) within the Canadian Province of Alberta. Created by William Wadsworth in ArcGIS Pro using available data from Esri, HERE, Garmin, FAO, NOAA, USGS, EPA, NRCan, and Parks Canada. 
to Lac Ste. Anne to assist with the running of the mission. Sisters Zoé Leblanc Emery, Adéle Lamy and Marie Jacques Alphonse arrived in Lac Ste. Anne not knowing how to speak Cree or Michif and helped run the mission (Emery to Deschamps 1859). They sent progress reports in letters of correspondence to their Mother Superior in Montreal, informing researchers of their daily lives. These documents are still available as several Lac Ste. Anne-related fonds in the Sisters of Charity in Montreal Archives (Alphonse, n.d.; Emery to Deschamps 1859); however, this paper uses partial English translations published in E. O. Drouin's (1973) Lac SteAnne Sakahigan. Nevertheless, although the diary was of a personal nature, one should be cautious about making strong assumptions about the Sisters' opinions of life in the settlement from the letters since they were reporting to their Mother Superior. Second, as an elderly Métis woman, Victoria Callihoo's (1960) recollections about her early life were recorded and published by the Alberta Historical Review in the 1950s. Born in 1862 to Alexis and Nancy Belcourt in Lac Ste. Anne, she later married Louis Callihoo in 1879 when she was seventeen (Anderson 1985). The young couple first lived in Lac Ste. Anne before moving to the Michel Reserve where they raised twelve children and owned a sawmill. Tragically, one of their sons, John, was killed in a sawmill accident, and the family moved back to Lac Ste. Anne (Anderson 1985). Callihoo later died in St. Albert at the age of 104 years old. Two considerations should be kept in mind when analyzing her stories. Somewhat obvious is the role that additional authors likely played in editing her story for publication and changing her voice. Furthermore, some authors have commented on memory's erasure with age, and Victoria was in her nineties when her recollections were recorded (Van Dyke 2008). Nevertheless, these documents can shed light on the dominant patriarchal narratives of Lac Ste. Anne.
Before embarking on this journey, it is important to discuss my relationality to this topic. I (Wadsworth) am a man and am not attempting to "give" these women their voice back. By writing this historical essay, I am merely trying to draw attention to inaccuracies that have pervaded the literature and further highlight how important these narratives could be to modern projects. In most instances, I quote the women as best that I can so that their own voices come through this paper. Furthermore, I am not going to be using feminist theory to examine and interpret these historical papers, although I suspect this would be highly productive, but I will be approaching these documents with the sensitivity and respect afforded from a twenty-first century lens. Prior to discussing how these women's narratives change our conceptions of the history at Lac Ste. Anne, it is imperative to review the historiographical context of these writings and the current narrative at the site.

\section{HISTORIOGRAPHICAL CONTEXT}

The challenge of this paper is that it draws from three distinct historiographies. Firstly, many historians have published widely on women's histories from the northern Great Plains (Laegreid and Mathews 2011). Secondly, although limited or overly hagiographical, Catholic Sisters in western North America have also received growing interest (Butler 2012). Finally, following the Daniels v. Canada decision, the field of Métis studies has grown exponentially and more in-depth debates concerning the roles of women have been investigated (Brown 1983; Macdougall 2016). To present an in-depth account of each of these historiographies would be extremely difficult and exceed the confines of this paper. Instead of attempting this difficult endeavour, this study draws on the work of historians Elizabeth Jameson and Jean Barman as they challenged the efficacy of overarching women's histories and argued for a shift in focus toward "little" histories or individual biographies 
(Barman 2008; Jameson 2008). These more nuanced histories can then be used to reconstruct and inform grander perspectives on history (Barman 2008; Jacobs 2017; Jameson 2008). This approach has been particularly effective in coaxing out Indigenous and nonIndigenous women's histories that were often overlooked or ignored by paternalistic historians writing regional or national narratives (Albers 2011; Barman 2008; Jacobs 2017; Jameson 2008). The following Lac Ste. Anne case studies hope to grow the productive corpus of little histories from Alberta and help to change problematic narratives. A central debate in Great Plains women's history has also been whether the "West" was good for women (McPherson 2000). This question has influenced the framing of this paper as the Reverend Fathers described women's roles as marginal due to the fact they were not suited to "isolated" prairie life (Drouin 1973). Other studies have challenged this assertion, but these have predominantly focused on white women as agricultural homesteaders (i.e., Jacobs 2017).

During the eighteenth and nineteenth centuries, Catholic Sisters were sent ahead of European settlers to evangelize Indigenous groups in western North America (Butler 2012). The Sisters' endeavours in establishing convents, churches, schools, and hospitals were usually recorded by the missionary Fathers (Drouin 1973; Duchaussois 1919). Although informative, these accounts are steeped with "fatherly concern," specifically in regard to the nuns' accomplishments and hardships they faced in the West (Butler 2012, 45). Although far fewer studies about Catholic Sisters have been undertaken in comparison to Women's histories in general, these too are increasing in number. Convent histories exist but are limited in their utility because they have been written by nuns and were typically framed in hagiographical rhetoric as they had to first be approved by the Church (Butler 2012, 5). This essay draws inspiration from
Anne Butler's (2012) work on Catholic Sisters in the American West, where she argued that these women found purpose in doing God's work, which challenged institutional narratives written by priests. Meanwhile, fewer scholarly works have focused on the Grey Nuns in Canada with the most influential work being Lesley Erickson's At the Cultural Religious Crossroads, which is an account of Sara Riel's life (Erickson 2011). Similar to the American Catholic Sisters, Sara Riel and the Grey Nuns challenge our understanding of western development and oversimplified models of colonialism by demonstrating the ability for Indigenous women to overcome racial boundaries and become nuns (Erickson 1997). In doing so, these religious women both served and transformed Indigenous landscapes and Indigenous-Settler relationships in Western Canada (Erickson 1997).

Similarly, Métis women's roles in shaping Indigenous histories of Western Canada are being increasingly realized (Kermoal 2016). These studies have contributed to the growing trend toward the incorporation of decolonization theory within women's history, which has attempted to disrupt power narratives, change research questions, and build a more inclusive Indigenous history. Brown (1983) argued that Métis women played a central role in fur trade society when marriages built kinship networks between European traders and Indigenous communities. She further argued that future studies into intergenerational gender and familial relationships would shed light on Métis social history (Brown 1983). Additionally, Payment (1996) and Kermoal (2016) have contributed to the understanding of Métis women's sense of place by arguing for their essential (yet difficult) roles within communities. Following the little histories theme, this essay has drawn inspiration from other biographic depictions of Métis women, such as Sara Riel, Marie Rose Delorme Smith, and Isabella Clark Hardisty Lougheed, who navigated the gender, race, class and religious 
boundaries that existed in Western Canada (Erickson 1997; MacKinnon 2018). These women have helped challenge the patriarchal narratives that shape Great Plains histories and have informed this essay's methodology.

\section{DOMINANT HISTORICAL NARRATIVES}

One of the oldest history books about the area, West of the Fifth: A History of the Lac Ste. Anne Municipality, begins with Lac Ste. Anne's "prehistoric history," which is comprised of a detailed description about the geological and paleontological information of the area (ACLSAHS 1959). As a side note, it is stated in West of the Fifth that Indigenous peoples (including Cree and Métis) also inhabited the area. They are, however, only infrequently mentioned throughout the rest of the book. The history of Lac Ste. Anne "began" in 1801 when David Thompson marked Lake Manitou on his map. West of the Fifth then asserted that the Métis and Indigenous communities moved into this "empty" area with the Hudson's Bay Company (HBC) and missionaries in the early 1840 s. It is asserted in West of the Fifth that, "Neither of these [early explorers] made any mention of settlement of Métis or of a single Métis family on any of the lakes in the vicinity of the [Lac Ste. Anne], which had there been any, they most certainly would have mentioned" (ACLSAHS 1959, 12).

Fr. Jean-Baptiste Thibault, an Oblates of Mary Immaculate priest, arrived at Manito Sakahigan on August 7th, 1843 (Drouin 1973). Captivated by the beauty of the lake and the number of its inhabitants, Fr. Thibault committed to establishing a mission along its shores which he named after the "grandmother saint" to parallel the Indigenous grandmother figure. Another Oblate priest soon joined him, Fr. Joseph Bourassa, and hey made a deal that Thibault would travel around the countryside and evangelize the Indigenous groups while Bourassa remained at Lac Ste. Anne to look after the Métis settlement (Drouin 1973). While Fr. Thibault evangelized the nearby groups, Fr. Bourassa organized the construction of a new church to be completed in 1852 (Drouin 1973). The Lac Ste. Anne church was the first to exist west of the Red River settlement, and it was significant as it created more ministerial jobs. Also in 1852, Fr. Albert Lacombe, a historical figure for evangelizing many First Nations in the Northwest Territories, arrived in Lac Ste. Anne to join forces with Fr. Bourassa (Hughes 1911). After arriving, Fr. Lacombe attempted to convert the Métis settlement into a farming community. It is explained that these efforts failed because of poor soil conditions, bad weather, and the unwillingness of the Métis to adapt (Drouin 1973).

In 1859, the Oblate priests convinced the Mother Superior of the Sisters of Charity (Grey Nuns) in Montreal to send three nuns to Lac Ste. Anne to assist the priests in running the mission (Drouin 1973). While there is little reference to the arrival of these women in West of the Fifth, the chief concern of the Reverend Fathers appears to be the well-being of these isolated nuns (Murphy et al. 2007, 101). Between 1862 and 1863, the Oblate Fathers and Grey Nuns moved the mission to St. Albert, taking a great portion of the settlement with them. Various reasons were given in West of the Fifth for the move to St. Albert, most of which relate to resource instability due to disappearing buffalo and lack of farming due to the Métis moving around the landscape, and these were ultimately interpreted by the priests as desertion (ACLSAHS 1959). At this point, there is a discontinuity in Lac Ste. Anne history, and there are few documents between 1863 and 1889, from when Fr. Joseph Lestanc returned to the lake to initiate the annual pilgrimage (Figure 2; Simon 1995). Today, pilgrims still flock to the shores of Lac Ste. Anne during July for healing, renewal, and reconnection. A literature review has shown that this patriarchal narrative can be 


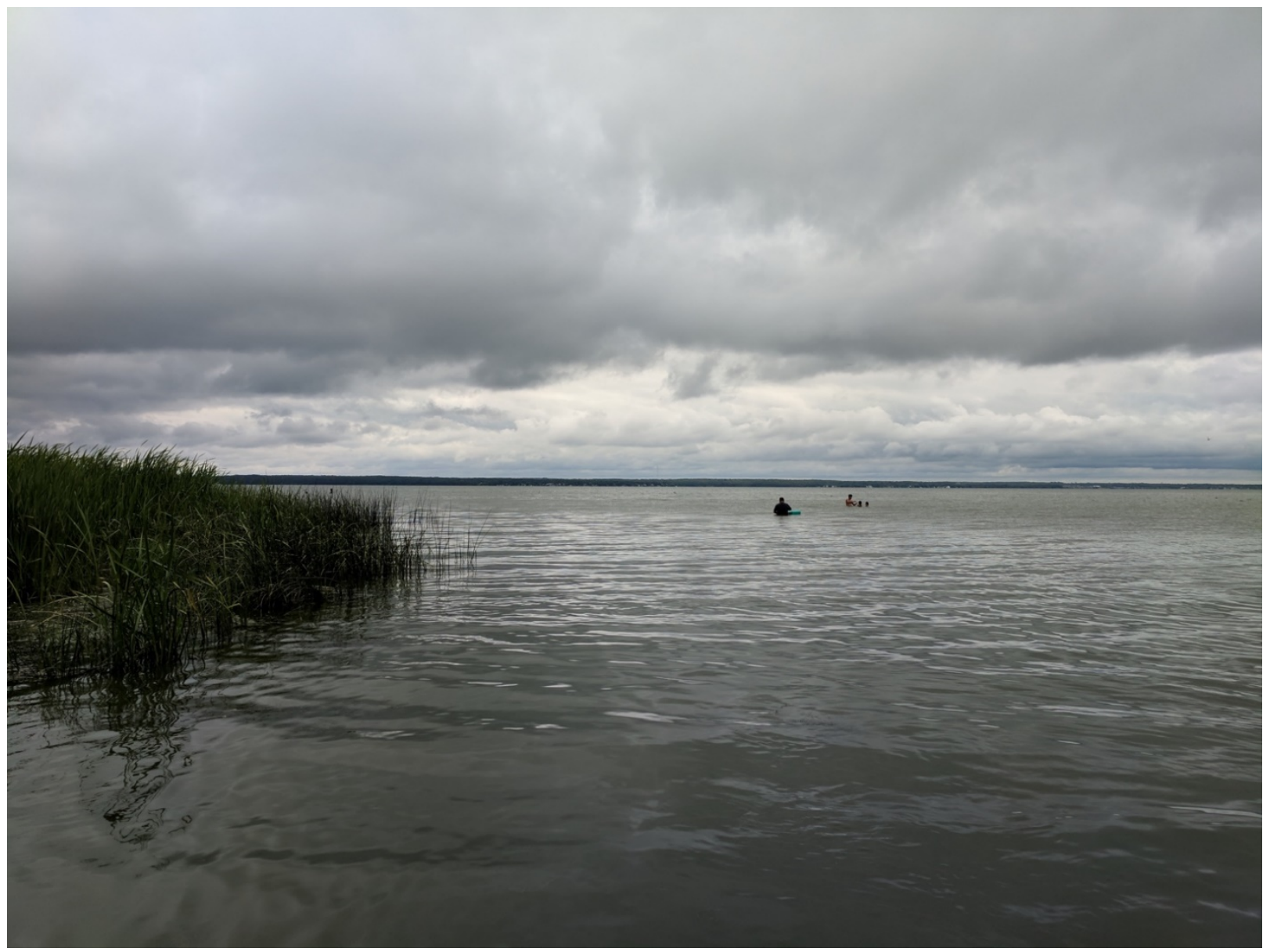

FIGURE 2 - Photograph of Lac Ste. Anne taken during the Lac Ste. Anne Pilgrimage in 2019 (Photo Credit: Rebecca Bourgeois)

considered as the generally accepted history of Lac Ste. Anne. ${ }^{1}$ However, historian Raymond Huel has demonstrated that the priests at Lac Ste. Anne had (in general) a hard time evangelizing the Indigenous inhabitants (Huel 1996). Although women and Indigenous actors make brief appearances in stories about the site, their contributions are short-lived, infrequent, and not fully considered. Using perspectives obtained through the Grey Nuns' documents and Victoria Callihoo's account, the following paragraphs present a more nuanced account of their lives at Lac Ste. Anne, specifically their responsibilities, wellbeing, mobility, and influence in and by colonialism, to challenge the aforementioned patriarchal history.

\footnotetext{
${ }^{1}$ In 1973, E.O. Drouin's (Oblate) work, Lac Ste. Anne Sakahigan was the first “comprehensive" history of Lac Ste. Anne to be published. As such, it has been reproduced (sometimes verbatim) in other histories of the site such as Davison's (1982) Lac Ste. Anne Spirit and Trails and Anderson's (1985) The First Metis... A New Nation. Although Lac Ste. Anne Sakahigan is descriptive, Drouin primarily drew on the work of early Oblate writers (such as Father Lacombe and Bishop Vital) who wrote down the chronicles of these communities. Currently, there are no histories that properly engage with the documents left behind by the Grey Nuns or the Métis history of the site (although Anderson attempted this). All current websites and popular literature seem to support the current narrative of the site as well.
} 


\section{FOUR WOMEN AT LAC STE. ANNE}

\section{Roles and Responsibilities}

When the Sisters came to Lac Ste. Anne, they had a very clear understanding of their roles. In letters written to Mother Deschamps, who was Mother Superior of the Grey Nuns in 1859, Sister Emery knew that they had come to the place that they would one day be buried (Figure 3; quoted in Drouin 1973). In the meantime, without fear, the women set upon their duties to God and became key figures in the settlement. Although Grey Nuns often received training in education and health care at the mother house, the limited biographical information about Sisters Emery, Lamy, and Alphonse makes it impossible to say whether they had prior experience with the roles they fulfilled at the settlement (Erickson 1997, 48). It was also revealed in Sister Emery's letters that as the eldest nun (31 years old), she assumed the position of Superior and

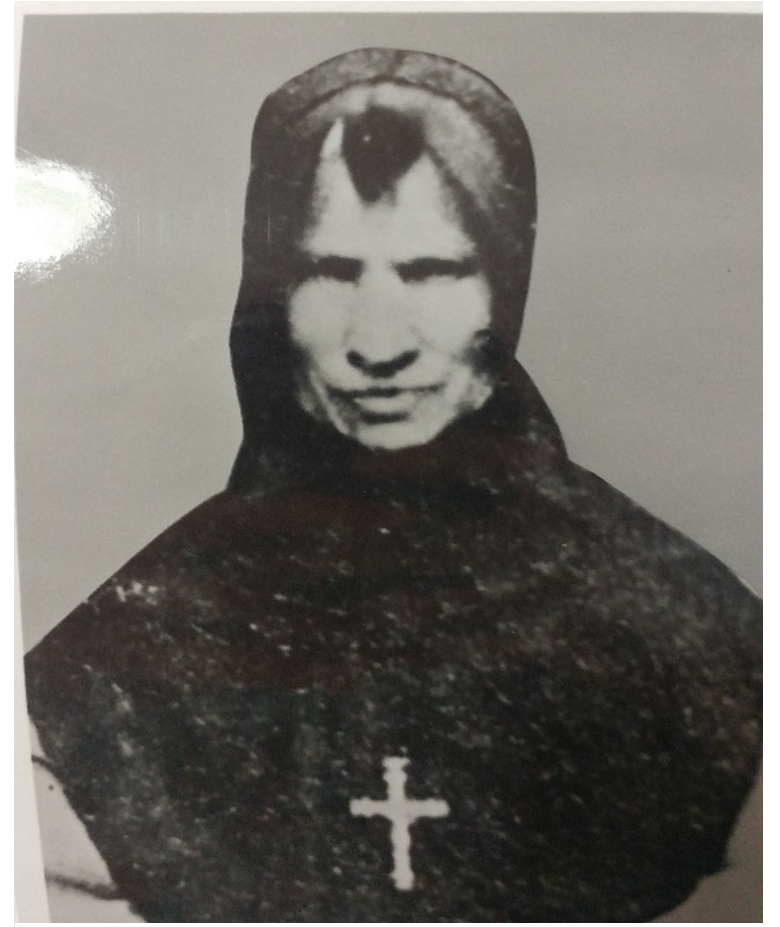

FIGURE 3-A portrait of Sister Emery (Zoe Leblanc) Foundress and Superior at Lac Ste. Anne (1859-1863), Grey Nuns Archives. established the first hospital in Alberta, which operated from their log cabin (Figure 3; quoted in Drouin 1973, 27-32). Sister Alphonse (22 years old) started the first school at Lac Ste. Anne and taught the settlement's inhabitants how to read, write, and recite prayers. Finally, Sister Lamy (23 years old) took care of the chapel and the priests' vestments. Each of the Sisters shared household duties, tended the mission's livestock, and were taught Cree for one hour a day by Fr. Lacombe (to better communicate with the Indigenous people). Emery wrote to Deschamps in 1859 that the Sisters travelled around the Lac Ste. Anne area acting as the local physicians to provide medical care for the Indigenous communities (quoted in Drouin 1973).

It is impossible to separate these women's roles and responsibilities from the institution that they represented. As Erickson summarized from the existing literature, the Reverend Fathers associated the Grey Nuns' roles in education and health care with "women's duties" and, as such, paternalistically looked down on them (Danylewycz 1999; Erickson 1997, 28-34). That being said, these roles allowed the nuns to function somewhat independently of the male religious hierarchy and cross boundaries within settlements (Erickson 1997, 28-34). There are currently no documents from the Lac Ste. Anne Métis concerning how they perceived the Grey Nuns' roles in the community. Although Erickson found that the Métis resented Sara Riel's attempts to teach them English, it is difficult to extend this to Lac Ste. Anne given that the French-speaking Grey Nuns appear to have been well-received and accepted by the French Métis community as indicated by Sister Emery's letters (quoted in Drouin 1973, 29-32; Erickson 1997, 129). As will be discussed later, since the day they arrived, the Métis community had welcomed and supported the nuns. On October 10th, 1859, Sr. Alphonse recorded that she had forty-two students of various ages in her 
classroom, who she taught for one hour per day (quoted in Drouin 1973, 30). The Sisters also took it upon themselves to help children they deemed in need (it is unknown how the Métis reacted to this). As Sister Emery noted:

A few days after our arrival we visited every single family. All appeared so pleased to see us. We have now taken in two girls, one ten and the other twelve. If the mission were rich enough, we could take in many more as it would be the best way to educate them. (quoted in Drouin 1973, 32)

Independent of the priests, it is impossible to deny that the Grey Nuns played an important role in the community of Lac Ste. Anne. That being said, it is difficult to say how these roles would have overlapped with those of the Métis women.

Like in many Indigenous societies, Métis women played foundational roles within their communities. These women likely obtained this central organizational role during the fur trade, when marriage alliances were made between Indigenous communities and European traders (Van Kirk 1999). Brown (1983) suggested that this practice created the matriorganization that has been found in other Métis community studies (for example, Batoche; Payment 1996; Supernant 2018). These women are scantily mentioned by current ethnocentric narratives that have conflated Indigenous men and women into one group that needed to be saved (ACLSAHS 1959; Drouin 1973). Although Victoria Callihoo did not explicitly comment on women's roles at Lac Ste. Anne, she did explain their essential roles in operating the buffalo hunt.

For much of the year, the Métis families survived on buffalo meat and sold buffalo robes obtained through the annual hunt (Callihoo 1953). This practice developed after the merger between the HBC and North West Company in 1821, which resulted in the unemployment of many Métis traders (Supernant 2018). These people were forced to redefine themselves, and they began to hunt buffalo in kin groups and adopt a highly mobile lifestyle (Macdougall and St-Onge 2013). There has been much written on the Métis hunt, but few articles have focused on the role of Métis women (Macdougall and StOnge 2013). Starting when she was thirteen, Victoria Callihoo remembered the four buffalo hunts she participated in as a young girl (Callihoo 1960, 24-25). The Lac Ste. Anne Métis were typically the families who began the hunt, being that they were the furthest away from the buffalo herds. The hunt was a gendered activity, and although it was organized and carried out by Métis men, women had a vital role in the operation of the hunt. Callihoo accompanied her mother, a well-known medicine woman, and helped set broken bones and apply medicines to wounded hunters (Callihoo 1960, 24-25). After the kill, the Métis women would process the meat and prepare it for storage and cooking. The buffalo hunts can also be thought of as a social affair and opportunity for reconnection among family members. Although it was a time of hard work, it was also a time of happiness and celebration (Callihoo 1960). The Lac Ste. Anne Métis women's roles as doctors, organizers, and maintainers of their social organization during the hunt is similar to other studies of Métis communities (Kermoal 2016; Macdougall and St-Onge 2013). Therefore, it is plausible that these women had similar responsibilities at home, which works to dispel the ethnocentric and over-simplistic narrative of the Oblate Fathers.

\section{Health, Diet and Living Conditions}

In contrast to the assumed struggles these women faced at Lac Ste. Anne, the Grey Nuns seem to have enjoyed a fairly comfortable life compared to the rest of the settlement. In preparation for their arrival, a log cabin was commissioned by Fr. Lacombe for the nuns 
(Drouin 1973, 31). In a 1859 letter to Mother Superior Deschamps, Emery explained that their house had five rooms and was substantially larger than any of the Métis living spaces (quoted in Drouin 1973, 31). The largest bedroom was about two by three meters and housed two Sisters. Emery also stated that the other rooms in the house were used as a classroom, prayer room, community room and chapel (quoted in Drouin 1973, 31). They also had a detached kitchen a few meters from the house, however, Emery divulged that they had to evict the Métis family who had been living there to use it (quoted in Drouin 1973, 31). Furthermore, the nuns' eating and sleeping arrangements vastly differed from the Indigenous inhabitants who were doing these activities on dirt floors. In the following quote, Sister Emery described in the 1859 letter that the Sisters were well fed and slept on feather beds with all the accoutrements:

This year the barley and potato crops have been good. As to wheat ... let's forget about it; we have already lost our taste for bread. The garden has furnished its share of cabbages, onions, turnips, carrots, etc. We eat fresh meat, pemmican, fish and rabbit in winter. Fish constitutes more than half our total fare. Many families have but fish boiled without salt and without sauce of any kind. We have as many potatoes as we desire, sometimes too some barley bannock . . . we never suffer from indigestion! Sisters Lamy and Alphonse have never been as plump, I am the only one to remain slim.

I must also, my good mother, tell you a word of our beds . . . Despite our repeated refusals, we have been forced to accept the beds of the Good Fathers. They have but animal skins to sleep on. We have a feather bed, a pillow and a blanket each. (quoted in Drouin 1973, 31; emphasis added)

In many ways, it is clear that when Sister Emery penned this letter, the three Sisters were in a good state of well-being. Fr. Lacombe credited the mission's move to St. Albert to the Métis' inability to farm, which had created inhospitable conditions (Drouin 1973, 37). Interestingly, as described by Emery, the Grey Nuns appear to be supported by the Métis of Lac Ste. Anne, whose diet consisted of dried meat, pemmican, bannock, and a few garden vegetables and tubers (Callihoo 1953; quoted in Drouin 1973, 31-32; Huel 1996, 65). The clergy even owned a number of animals, including fifteen horses, seventeen cattle, ten dogs, and ten cats. Unlike male authors who described the Sisters' diet as meagre, documents from the Sisters suggested they were healthy and that they worried for the struggling Métis (Drouin 1973; Duchaussois 1919; quoted in Drouin 1973, 31).

According to the clerical community, the Métis of Lac Ste. Anne might as well have lived in impoverished conditions (Callihoo 1953). Simply, the luxuries that the clergy was afforded were not necessary for the Métis to live. They either pitched tipis or lived in oneroom log cabins that averaged around eight by five meters in their entirety (Burley and Horsfall 1989; Callihoo 1953). Since the Métis were Roman Catholics, they tended to have large families, which resulted in cramped living spaces. Each home usually had two windows that were covered with stretched animal skin. Floors consisted of compacted dirt or hewed logs placed tightly together. Dried bark was used to shingle the roofs of these cabins. The Métis used open fireplaces in the corners of the cabin to cook food and heat their homes (Callihoo 1953, 22). Around these stoves, the floor was often plastered to keep the cabin from catching on fire. It is well documented historically and archaeologically that 
the Métis relied on the HBC store for much of their goods (Supernant 2018). Callihoo (1953, 22) recalled that all the tools and supplies they needed for day-to-day life were obtained at their local trading post. Callihoo's family slept on the floor and each morning their bedding was gathered, folded, and placed in one corner of the house. Their bedding consisted of duck and goose feather mattresses, pillows, buffalo robes, and HBC four-point blankets. Despite these closed quarters, the Métis were still known to hold many parties (Callihoo 1953, 23, 25-26; Supernant 2018; Weinbender 2003). Throughout the year, people commonly held dances in their homes, which drew family and friends from surrounding communities.

Although there were likely times of shortage, Callihoo's account calls into question the starvation narrative promoted by the clerical community when she did not recall her family ever being short on food (Callihoo 1953, 2225). After the buffalo disappeared, the Lac Ste Anne Métis more heavily relied on the fish from the lake, which was a phenomenon seen in other Métis communities (Supernant 2018). Furthermore, by the 1860 s and 1870 s, many Métis families had begun to farm (just like Victoria's family had), raise livestock, and supplement their diet with hunted moose, deer, and bear (Anderson 1985; Callihoo 1953). The only grievance Callihoo mentioned was that, at first, the Métis did not care for beef. They learned to like it once they realized they only needed to butcher one or two cows to sustain a family through the winter. Like the Grey Nuns, Victoria Callihoo's recollections of Métis life and living conditions adds compounding evidence against the existing patriarchal history of Lac Ste. Anne.

\section{Women's Physical and Social Mobility}

There is no clear "rule" of how women's physical and social mobility was changed by colonialism and the West (McPherson 2000). The women at Lac Ste. Anne seem to fall into the category of increased physical freedom compared to their counterparts in "civilization." The Grey Nuns from Lac Ste. Anne possessed some autonomy in order to accomplish their religious duties. Emery indicated in her 1859 letters to Mother Superior Deschamps that it only took the Sisters a few days upon their arrival to visit every family in Lac Ste. Anne, and they travelled frequently through the countryside to care for Indigenous families (quoted in Drouin 1973).

As previously mentioned, Erickson (1997) found that in some communities, nuns found incredible social mobility independent of the Catholic priests (24-28). In general, the Sisters seem to have been well-received by the Lac Ste. Anne inhabitants. Emery reported that at least thirty people came out to welcome them when they first arrived (quoted in Drouin 1973, 29). Since the founding of the first mission in 1843, the settlement had grown, and Sister Emery realized that the locals were too numerous for the small church as they would often be lined up outside to attend holy communion (quoted in Drouin 1973, 30). If the Sisters had not been as holistically accepted by the devout Métis community, their experiences likely would not have been as positive. Despite these unequivocally good experiences, there were still difficulties in navigating the social world of Lac Ste. Anne. In her daily journal, Sister Alphonse recognized the difficulty in communicating with the "medley of nations" at Lac Ste. Anne (quoted in Drouin 1973, 30). To accommodate for this, the Sisters had been learning Cree from Fr. Lacombe. As their roles differed from the priests (whose goal was evangelism), it is likely that the nuns were viewed differently and had a different understanding of life in Lac Ste. Anne.

Many studies have emphasized the incredible physical and social mobility of the Métis during the late- to post-fur trade time periods, and the Lac Ste Anne Métis were no exception (MacKinnon 2018; Van Kirk 1999). Often settlers and missionaries had a hard time finding the Métis due to their tendency to move. 
Fr. Thibault chased Piché (the man who requested a permanent Catholic mission) around Alberta before finally finding him near Rocky Mountain House (Drouin 1973). Similarly, the Métis are famous for travelling vast distances to hunt buffalo (Macdougall and StOnge 2013). Furthermore, during the buffalo hunts, one Métis man would be elected to go to the Red River settlement to obtain supplies that were not readily available (e.g. plows and garden tools) and usually came back with more families who aimed to settle at Lac Ste. Anne (Callihoo 1953). If that was not enough cart travel for one season, after the hunt was over, some people would then travel to Morley, Alberta to trade horses with the Blackfoot (Callihoo 1953, 25). The Lac Ste. Anne settlement's proximity to St. Albert and Edmonton permitted families to visit each other frequently and attend social events held in nearby communities. Some Métis families kept ponies or dog trains for fast travel to events such as weddings or dances or for urgent matters like fetching the priest in case of sickness (Callihoo 1953, 21-26). Simply, Métis men and women were not averse to longdistance travelling in order to get the items they needed or desired. Callihoo (1953) commented on the travel back from buffalo hunting in southern Saskatchewan,

The homeward journey was slow, but who cared? The nice sunny days in the fall, Indian summer, made travelling rather fascinating. Occasionally we would run into bad weather, but we were accustomed to it and did not mind as long as we had plenty of the best and most nourishing food I ever ate. (25)

Given this wide range of interaction between settler and Indigenous communities, it is pertinent to also consider Métis women's social mobility. Despite often being pillars of their communities (Brown 1983; Van Kirk
1999), it is important to emphasize that Métis women did what they had to in order to survive. MacKinnon described two accounts of Métis women who hid their heritage to progress in society, and this was not uncommon (MacKinnon 2018, xii-xxviii). In Lac Ste. Anne, following her son John's and husband's deaths, Callihoo owned and operated a hotel and bar for several years to provide for her family (Anderson 1985). Like the Grey Nuns, the Lac Ste. Anne Métis are painted as rooted in place by the dominant narratives, but in reality, these women exercised their freedom and physical and social mobility.

\section{Women and Colonialism}

Although the Grey Nuns occupied a different role than the Oblate Fathers, Erickson (1997, 108) argued that they still shared the belief that Christianity and a sedentary lifestyle would benefit Indigenous people. In the translated documents left by the Sisters, there is little to suggest that they were active agents in colonialism. Nevertheless, the Grey Nuns likely subconsciously propagated an independent form of colonialism that was different from the Oblate Fathers (Erikson 1997). They evangelized with the hopes of creating a new Catholic West (Butler 2012; Huel 1996, 65). Furthermore, Sr. Alphonse documented in her journal that she taught French to the Indigenous people at Lac Ste. Anne but does not mention how it was received (quoted in Drouin 1973, 30). In a way, the nuns' silence on the matter may speak volumes about their relationship with the community as proponents of colonialism.

While notable that the Métis could function at higher classes of both Euro-Canadian and Indigenous society (MacKinnon 2018), Callihoo (1953) subtly re-emphasized a particular distinction:

Métis from Lac Ste. Anne and St. Albert often visited each other, that is once or twice a year. These two settlements were of the same 
people, and they were related mostly. There would be a man or a family from Lac La Biche or Slave Lake who would come and live in the settlement. The two Settlements were all Catholics, L'Hirondelle, Belcourt, Gladu, Plante, Laderoute and Gautheir, were of French descent. (23; emphasis added)

We used to see Battle River people, off and on. Since they were Métis of French extraction like us, good fellowship prevailed, and some marriages took place. We did not come in contact with the Métis at Victoria, their being of Anglo-Saxon descent and of a different denomination, no visits, to my knowledge, were ever made to them. (26; emphasis added)

She noted that ethnic and religious categories created social boundaries that were not crossed in Métis society. Simply, French Catholic Métis men and women only had relationships with similar families. These linguistic and religious boundaries were also noted in the journals of the bishops who were concerned with the growth of Protestantism in the region, promoted by English speakers and the HBC (Grandin 1989). With this in mind, the Catholic pilgrimage to Lac Ste. Anne would have been an opportunity to meet other French Catholic families and arrange marriages and partnerships (Simon 1995). Although, this separation has not gone unnoticed by historians, who have attempted to make a distinction between the French "Métis" and English "Metis /half-breeds," Callihoo has demonstrated the reality of this boundary.

This social boundary is significant to how colonialism impacted Métis social structure in Lac Ste. Anne and the surrounding area. Carter (1997) argued that colonialism refers to the asymmetrical relationships and impacts that were created by highly varying administrative forces as a result of colonial rule (19). Similar to Frits Pannekoek's argument for social structures among the Red River Métis, the Lac Ste. Anne Métis (at least by Callihoo's account) seemed to internalize differences created by religious organizations, which subsequently influenced how they interacted with different Indigenous communities. ${ }^{2}$ The Métis of Lac Ste Anne held significant economic power given their role in supporting the mission; however, the clergy encouraged colonialism by guiding inter-settlement interaction, further cementing religious boundaries. In the same area, this religious boundary is also seen in the nearby Alexis Nakota Sioux and Paul First Nations, which formed after Catholic and protestant members of the same group split from each other in 1880 (Andersen 1970). This finding is significant as it gives insight into how the religious narratives that this essay is challenging created new identities and realities for Indigenous peoples at Lac Ste. Anne.

\section{CONCLUSION}

The Greys Nuns and Callihoo have shed light on aspects of women's life in the Lac Ste. Anne settlement. If the arguments and opinions set out in the existing literature are taken as fact, then this site would support the assumption that women were unhappy, isolated beings living in a place lacking the

\footnotetext{
2 There is a central debate in Métis history about the origin of Métis social structure at the Red River settlement, which Irene Spry and Frits Pannekoek have argued about. Spry argued that the Red River Métis society was organized around a distinct economic class structure, which was a position later widely adopted in Métis studies. In contrast, Frits Pannekoek argued that this class society originated from and was ratcheted by the clergy. Please see, Nicole St-Onge and Carolyn Podruchny, "Scuttling Along a Spider's Web: Mobility and Kinship in Metis Ethnogenesis." in Contours of a People: Métis Family, Mobility, and History, eds. Carolyn Podruchny, Brenda Macdougall, and Nicole St-Onge, (Norman: University of Oklahoma Press, 2012), 59-92.
} 
comforts suited to their gender. Yet, when first person perspectives or "little histories" from the Grey Nuns and Callihoo are considered, narratives of life at Lac Ste. Anne change drastically. Specifically, their responsibilities, living conditions, mobility, and relationships with colonialism have exposed issues with the current religious history. The Métis community economically supported the nuns, and the nuns (albeit whose goal was to Christianize) took care of their congregation through physical and spiritual healing (Callihoo 1953; Huel 1996). Although the Grey Nuns' letters are brief, there is no reference to any hostile attitudes towards the Métis or Indigenous communities. Instead, the Grey Nuns passively advocate for the Métis in their writings to their Mother Superior, suggesting a more complicated reciprocal relationship, or at least one where power was still somewhat shared between the Métis and the missionaries. Like Erickson, this finding is not meant as an alibi for colonialism but to highlight the entanglements that existed within these religious racially mixed communities (Erickson 2011, 134). Similarly, having lived on the Northern Plains for generations, the Métis did not need to be "saved" as patriarchal narratives may suggest. Differences in lifestyles abounded in the Lac Ste. Anne settlement, and the religious community often did not understand Métis practices, such as the buffalo hunt. In the settlement, gender divisions were clear, and the Grey Nuns and Métis women had important responsibilities for the upkeep of the settlement. They embraced these responsibilities as they allowed them to be physically mobile across the landscape and defy "isolated" assumptions. Although Sister Emery admitted in her letters to Deschamp that she sometimes found herself quite lonely, she was also inspired by her purpose to do God's work (which included caring for the Indigenous communities; quoted in Drouin 1973). Despite what appeared to be productive relationships, inequality existed within the Lac
Ste. Anne settlement. The Grey Nuns lived in a multi-roomed house, were well fed by the community, and had lots of livestock, while the Métis lived in much more modest conditions (quoted in Drouin 1973). As articulated in the historiography, one debate in western women's history has been whether the "West" was good for women (McPherson 2000, 7586). Broadly speaking, the West appears to have been good for Lac Ste. Anne women; however, upon a more nuanced look, it is equally true that the settlement was better for some women than others.

Women's histories have exposed the issues with and cast doubt upon the dominant religious narratives at Lac Ste. Anne. These narratives marginalized both white and Indigenous women and perpetuated stereotypes to justify colonial actions (Albers 2011). White women were treated as second-class citizens that needed to be protected against the wilderness and its severities, while Indigenous women were almost completely left out of histories besides a few accounts that depicted the missionaries saving children from unfit mothers (Carter 1997; Drouin 1973). Both the Grey Nuns and Callihoo's accounts argued against these pejorative narratives. Simply, these women did not need saving and were understood as valuable members of the Lac Ste. Anne community entrusted to be teachers, doctors, farmers, and hotel owners, supporting the findings concerning women's roles seen elsewhere in fur trade era and post-fur trade era Canada (Racette 2012; Van Kirk 1999). Additionally, the Lac Ste. Anne case study has provided an example of how site-specific or "little histories" approaches can challenge a patriarchal narrative from subaltern perspectives (Barman 2008; Jameson 2008). Given the limited scope of this essay, it is difficult to extend this biography-specific approach to a national history, and even more speculative to extend this to a transnational history. Nevertheless, in the future, this topic would greatly benefit from a comparative analysis of 
women's histories from other sites across the Prairies and on both sides of the border.

This essay has only focused on two case studies from the Métis community at Lac Ste. Anne, and given the existence of many recorded family and life stories, this research is far from complete (Anderson 1985; Davison 1982). Lac Ste. Anne was a complex community with missionaries subverting the autonomy of indigenous inhabitants through evangelism. That being said, relationships were not antagonistic as the missionaries depended on the Métis to survive in the Northwest. Reciprocally, the Métis needed priests and nuns to fulfill their religious needs, as well as educate their children and act as local doctors. These case studies have supported the notion that Métis communities were not isolated, but rather were part of specific kinship/religious/ linguistic networks that were regularly maintained by these families and influenced by the different clergies. Although this study was limited by its geographic and temporal focus, it is significant because the Grey Nuns' and Callihoo's stories have changed our view of Lac Ste. Anne, and thus have changed our understanding of colonial relationships and bias in the historical record and lent the site for future comparative studies.

\section{REFERENCES}

ACLSAHS (Archives Committee Lac Ste Anne Historical Society). 1959. West of the Fifth: A History of Lac Ste. Anne Municipality. Edmonton: Institute of Applied Art.

Albers, Gretchen. 2011. "Glimpsing the Lives of Women on the Northern Great Plains, 1803-1862." In Women on the North American Plains, edited by Renee M. Laegreid and Sandra K. Mathews, 29-47. Lubbock: Texas Tech University Press.

Andersen, Raoul R. 1970. "Alberta Stoney (Assiniboin) Origins and Adaptations: A
Case for Reappraisal." Ethnohistory 17, no. 1/2 (Winter-Spring): 49-61.

Anderson, Anne. 1985. The First Métis . . . A New Nation. Edmonton: UVISCO Press.

Barman, Jean. 2008. "Writing Women into the History of the North American Wests, One Woman at a Time." In One Step over the Line: Toward a History of Women in the North American Wests, edited by Elizabeth Jameson and Sheila McManus, 99-127. Edmonton: University of Alberta Press.

Burley, David V. and Gayel A. Horsfall. 1989. "Vernacular Houses and Farmsteads of the Canadian Métis." Journal of Cultural Geography 10, no. 1: 19-33.

Brown, Jennifer S. H. 1983. "Woman as Centre and Symbol in the Emergence of Métis Communities." The Canadian Journal of Native Studies 3, no. 1: 39-46.

Butler, Anne. 2012. Across God's Frontiers: Catholic Sisters in the American West, 1850-1920. Chapel Hill: University of North Carolina Press.

Callihoo, Victoria. 1953. "Early Life in Lac Ste Anne and St. Albert in the Early 1870s." Alberta Historical Review 1, no. 3 (November): 21-26.

Callihoo, Victoria. 1960. "Our Buffalo Hunts." Alberta Historical Review 8, no. 1 (Winter): 24-25.

Carter, Sarah. 1997. Capturing Women: The Manipulation of Cultural Imagery in Canada's Prairie West. Montreal: McGillQueens University Press.

Danylewycz, Marta. 1999. Taking the Veil: An Alternative to Marriage, Motherhood, and Spinsterhood in Quebec, 1840-1920. 
Toronto: Oxford University Press.

Davison, Vi, ed. 1982. Spirit and Trails of Lac Ste. Anne. Alberta Beach: Alberta Beach and District Pioneers and Archives Society.

Drouin, E.O. 1973. Lac Ste-Anne Sakahigan. Edmonton: Editions de l'Ermitage.

Duchaussois, R. P. Pierre. 1919. The Grey Nuns in the Far North (1867-1917). Toronto: McClelland \& Stewart.

Erickson, Lesley. 1997. "At the Cultural and Religious Crossroads: Sara Riel and the Grey Nuns in the Canadian Northwest, 1848-1883." Master's thesis, University of Calgary.

Erickson, Lesley. 2011. "Repositioning the Missionary: Sara Riel, the Grey Nuns, and Aboriginal Women in Catholic Missions of the Northwest." In Recollecting: Lives of Aboriginal Women of the Canadian Northwest and Borderlands, edited by Sarah Carter and Patricia Alice McCormack, 114-134. Edmonton: Athabasca University Press.

Grandin, Vital Justin. 1989. The Diaries of Bishop Vital Grandin. Translated by Alan D. Ridge. Edmonton: Historical Society of Alberta.

Huel, Raymond J. A. 1996. Proclaiming the Gospel to the Indians and the Métis. Edmonton: University of Alberta Press.

Hughes, Katherine. 1911. Father Lacombe: The Black-Robe Voyageur. New York: Moffat, Yard and Company.

Jacobs, Margaret D. 2010. "Getting out of a Rut: Decolonizing Western Women's History." Pacific Historical Review 79, no. 4 (November): 585-604.

Jacobs, Margaret D. 2017. "Reproducing White Settlers and Eliminating Natives: Settler Colonialism, Gender and Family History in the American West." Journal of the West 56, no. 4 (Fall): 13-24.

Jameson, Elizabeth. 2008. "Connecting the Women's Wests." In One Step over the Line: Toward a History of Women in the North American Wests, edited by Elizabeth Jameson and Sheila McManus, 5-47. Edmonton: University of Alberta Press.

Kermoal, Nathalie. 2016. "Métis Women's Environmental Knowledge and the Recognition of Métis Rights." In Living on the Land: Indigenous Women's Understanding of Place, edited by Nathalie Kermoal and Isabel AltamiranoJiménez, 107-137. Edmonton: Athabasca University Press.

Laegreid, Renee M. and Sandra K. Mathews, eds. 2011. Women on the North American Plains. Lubbock: Texas Tech University Press.

Macdougall, Brenda. 2016. "The Power of Legal and Historical Fiction(s): The Daniels Decision and the Enduring Influence of Colonial Ideology." The International Indigenous Policy Journal 7, no. 3: 1-6.

Macdougall, Brenda and Nicole St-Onge. 2013. "Rooted in Mobility: Métis BuffaloHunting Brigades." Manitoba History 71 (Winter): 21-33.

MacKinnon, Doris J. 2018. Métis Pioneers: Marie Rose Delorme Smith and Isabella Clark Hardisty Lougheed. Edmonton: University of Alberta Press. 
William T.D. Wadsworth | Healing Waters and Buffalo Bones: Using Women's Histories to Challenge the Patriarchal Narrative of Lac Ste. Anne, Alberta

McPherson, Kathryn. 2000. "Was the Frontier 'Good' for Women?: Historical Approaches to Women and Agricultural Settlement in the Prairie West, 1870 1925." Atlantis 25, no. 1 (Fall): 75-86.

Murphy, Peter John, Robert Udell, Robert E. Stevenson, and Thomas W. Peterson. 2007. A Hard Road to Travel: Land, Forests and People in the Upper Athabasca Region. Hinton: Foothills Model Forest.

Palmer, Howard and Tamara Palmer. 1990. Alberta: A New History. Edmonton: Hurtig Publishers.

Payment, Diane. 1996. “'La Vie Een Rose'? Métis Women at Batoche, 1870-1920." In Women of the First Nations: Power, Wisdom, and Strength, edited by Christine Miller and Patricia Marie Chuchryk, 1938.Winnipeg: University of Manitoba Press.

Racette, Sherry F. 2012. "Nimble Fingers and Strong Backs: First Nations and Métis Women in Fur Trade and Rural Economies." In Indigenous Women and Work: From Labour to Activism, edited by Carol William, 148-162. Champaign: University of Illinois Press.

Simon, Steve. 1995. Healing Waters: The Pilgrimage to Lac Ste. Anne. Edmonton: University of Alberta Press.

Soeur Alphonse. n.d. Daily journal. Lac Ste. Anne Mission Fonds, Sisters of Charity Archives, Montreal, Quebec. Partial translation available in Drouin, E.O. Lac Ste-Anne Sakahigan. Edmonton: Editions de l'Ermitage, 1973.
Soeur Emery (Zoe Leblanc) à Mere Deschamps, Mission du Lac Ste Anne, 4 Decembre 1859. Lac Ste. Anne Mission Fonds, Sisters of Charity Archives, Montreal, Quebec. Translated in Drouin, E.O. 1973. Lac Ste-Anne Sakahigan. Edmonton: Editions de 1'Ermitage.

St-Onge, Nicole and Carolyn Podruchny. 2012. "Scuttling Along a Spider's Web: Mobility and Kinship in Métis Ethnogenesis." In Contours of a People: Métis Family, Mobility, and History, edited by Nicole St-Onge, Carolyn Podruchny, and Brenda Macdougall, 5992. Norman: University of Oklahoma Press.

Supernant, Kisha. 2018. "Archaeology of the Métis." Oxford Handbooks Online. https://doi.org/10.1093/oxfordhb/9780199 935413.013.70

Van Dyke, Ruth. 2008. "Memory, Place, and the Memorialization of Landscape." In Handbook of Landscape Archaeology, edited by Bruno David and Julian Thomas, 277-284. London: Routledge.

Van Kirk, Sylvia. 1999. Many Tender Ties: Women in Fur-Trade Society, 1670-1870. Winnipeg: Watson \& Dwywer.

Weinbender, Kimberley D. 2003. "Petite Ville: A Spatial Assessment of a Métis Hivernant Site." Master's thesis, University of Saskatchewan.

\section{CASES CITED}

Daniels v. Canada (Indian Affairs and Northern Development), 2016 SCC 12, [2016] 1 S.C.R. 99 (Can.). 